\title{
Career orientation of secondary school students $(\mathrm{m} / \mathrm{f})$ in the Netherlands
}

\author{
Remke Klapwijk • Els Rommes
}

Published online: 13 November 2009

(C) The Author(s) 2009. This article is published with open access at Springerlink.com

\begin{abstract}
In this paper, a new perspective is developed to promote a positive relationship between young people and technology. An in-depth study of the values young Dutch secondary school students feel are essential in their future profession was made. Following organisational psychologist Edgar Schein, we distinguish career anchors, each with their own core value. These core values show that differences between young people are considerable and explain why it is often so difficult to get grip on the decisive factors in the choice of a career. Although all girls have to deal with the masculine image of technology, they are not a homogenuous group as they pursue different values. Many of the anchors can be fullfilled by following study and career path in technology. However, current careers in technology are insufficiently associated with values such as creativity, service, autonomy and entrepeneurial. The educational system has been emphasizing the functional, expert anchor, but is gradually changing and preparing for the rise of the creative society that has been described by the economist Richard Florida. In contrast with Schein, we show that career anchors can already be indentified in secondary school students and added a new anchor identity.
\end{abstract}

This paper was translated from Dutch to English by: Ron Peek, Peek Language Services Ltd. For the Language Centre, Modern Foreign Languages Unit, University of Glasgow.

A Dutch version of this paper has been published by STT Netherlands Study Centre for Technology Trends as part of a foresight study (Bras-Klapwijk 2005).

R. Klapwijk $(\bowtie)$

Science and Technology Expert Centre West, The Hague, The Hague University, The Hague,

The Netherlands

e-mail: r.m.klapwijk@hss.nl

R. Klapwijk

Science Education and Communication, Faculty of Applied Sciences, Delft University of Technology, Delft, The Netherlands

E. Rommes

Institute for Gender Studies, Radboud University, Nijmegen, The Netherlands

e-mail: e.rommes@pwo.ru.nl 
Keywords Career anchor - Technology - Secondary school students ·

Edgar Schein - Career choice

\section{Introduction}

According to the Dutch 'Delta plan for Science and Technology' (OC\&W 2003), technical training and professions should be made more attractive to women. The technical sector can no longer afford to overlook female talent, particularly since interest by men can no longer be taken for granted. Perhaps an even more important reason to examine the career choices of secondary school students is that if such choices are based on an inaccurate image, such students may eventually end up in a profession where they will not feel at home.

Why is it that technology and natural sciences still seem to be a rather male-dominated area? An effective approach for achieving a higher number of women in technical careers has not yet materialised in the Netherlands. Efforts have not resulted in any significant increase in women undertaking technical education and training. For the last decade, the percentage of female students has remained more or less stable, at approximately $10 \%$ for senior secondary vocational education ('mbo') and $15 \%$ for higher professional education ('hbo') in the Netherlands. For technological studies at university level, the percentage of female students is $17 \%$. This number is twice as high for natural science studies, such as physics, chemistry and physical geography, but even in these areas women are still a minority (Buis et al. 2003; CBS 2004). Even in new technology sectors, such as information technology, the percentage of women remains quite low. Only $10 \%$ of those studying information technology and mathematics in Dutch higher professional education are female. This percentage increases to $49 \%$ elsewhere in Europe and in South Korea women even outnumber men in the field of ICT (Bongers et al. 2003). The low percentage in the Netherlands compared to other countries shows that the low percentage of women cannot be solely ascribed to potential genetic factors. In other words, additional obstacles in the form of social and cultural factors need to be taken into account.

In this paper, we consider the factors that lead secondary school students in the Netherlands to choose a technological education. We were interested in finding information about the 'dream jobs' of students, aged between 15 and 17 years, in preparatory secondary vocational education ('vmbo'), senior general secondary education ('havo') and pre-university education '(vwo'). In-depth interviews were conducted with 26 students from different areas within preparatory secondary vocational education or who studied different subject clusters within pre-university education. During the interviews, students were asked about their choice of studies, their interests, any part-time jobs they had, as well as their dream job. We also organised two careers workshops, where students could speak with technicians and natural scientists (van Damme 2004; Post 2005). By relating the ideas that young people have about their dream job to technical professions, we can indicate how these professions can be made more attractive to this group, as well as which additional measures would be required in relation to girls.

Girls are often treated as a homogeneous group in relation to their recruitment for technical professions. Nevertheless, girls-as well as boys-have very different professional values and also differ significantly between themselves with respect to "what they definitely did not want to compromise on in a job' when facing difficult choices. Following the work of Stein, an organisational psychologist, we will distinguish between a large number of career anchors, each containing a separate and distinctive core professional 
value. Each career anchor requires a specific approach in relation to making (partially) technical professions more attractive. They also provide an explanation as to why the decisive factors involved in encouraging the choice of a technical career, as examined in research and discussed in social debates, remain so elusive. What makes a particular profession attractive to one group, may not apply at all to another. A wide range of educational and career options are required in order to reach students in all anchors.

Despite the fact that girls have wide-ranging professional values and form a heterogeneous group, the masculine image remains an important and persistent obstacle. The belief that girls do not like to work with physical objects is also quite pervasive. We use the theory of career anchors to explain why women often tend to opt for a non-technical career, as long as technology remains associated with masculinity. Women need to be given the explicit message that technology, in all its aspects, is suitable for women.

\section{Factors affecting career choice}

Various studies have shown that students will opt for technology if they have come into contact with technology in a positive way, are confident in being good at technical things, have certain skills and experience in the area, and when a technical profession matches their self-image (see Eccles 1987; Schein 1987). Women fall behind with respect to these factors: girls tend to come into contact with technology less often, thereby acquiring less skills and knowledge. They also tend to be less confident (Orenstein 2000)—in particular, in their own technical abilities-and technology does not fit with their self-image. Such inclusion in their self-image often fails as a result of girls being exposed to technology and technical areas through male role models, such as fathers (Diemen et al. 2004). This results in a conflict between the interest developed in technical areas and their femininity, particularly since young people create their self-image in reaction to the opposite sex during their adolescence. For girls, this may result in an aversion to all things technical, since they represent masculinity and the things boys do.

Self-image is probably the most significant factor out of the following: positive experiences, self-confidence, competence, and self-image. Nearly all girls in Dutch primary schools that we interviewed liked technology and found it interesting and important. Yet most girls indicated that a technical profession, or one involving natural sciences, was 'not for me' (Bras-Klapwijk 2005). Similar findings were indicated by a study of approximately 160 girls who participated in Technika 10-clubs (Eck and van Volman 1999). All the girls who participated in these girls-only technology clubs came away with positive experiences in relation to using technology, as well as acquiring technical competence and an increase in self-confidence. Nevertheless, these girls believed that a technical profession would not suit them, since it did not fit with their self-image. One counterexample is that of Esther, one of the secondary school students we interviewed. Although exact science subjects do not come easy to her, and she no longer takes the Nature and Technology subject cluster, she still holds on to her dream job of becoming an architect or structural engineer, since it fits with her self-image. She says: 'I have always been occupied with taking things apart and putting them together again.... Normally, when I walk down the street, I just have to look at buildings, which always makes me wonder how they are put together.'

In the remainder of this article, we will examine the question of which values and selfimages young people uphold in relation to work-how they see themselves and what they want to achieve-and the extent to which such perceptions match the values they believe they will find in technological professions. 


\section{Personality types: masculinity vs. femininity}

In order to do justice to the various reasons why boys and girls choose technology, we will turn to the six personality types distinguished by career-choice researcher Holland (1997) (see Fig. 1). It is often believed that some personality types, particularly those orientated towards 'things', tend to occur more among men, whereas others, more 'people'-orientated ones, occur more among women (Lippa 2001).

Lippa's distinction between masculine/feminine, things/people can be criticised for a number of reasons. First of all, not all 'things' and/or technologies fall within the male domain in our society. For example, research involving primary school pupils has shown that girls actually gain more experience with techniques involved in sewing, cooking or cleaning (Bras-Klapwijk 2005). However, the activities carried out by women were not regarded as technical activities, even if they involved the handling of advanced equipment and actions pertaining to sewing. Furthermore, even if areas of study such as fashion and design, history and philosophy are forms of education in which things, numbers and ideas are more frequently used than people, they predominantly attract girls. Apparently, the masculine or feminine image of a particular kind of education is a much more decisive factor than whether or not it involves working with things or people. The definition of technology used in our culture has become inextricably linked with our definition of masculinity (Cockburn and Omrod 1993; Wajcman 1993).

Secondly, the continuous repetition of the dichotomies men/technology, women/people is not without danger. Such repetition makes it virtually impossible to loosen the unilateral connection between women and people and that between men and things. As a consequence, stereotypical images of women are reinforced and not much attention is given to their career ambitions and their fascination with all things technical. Women are more

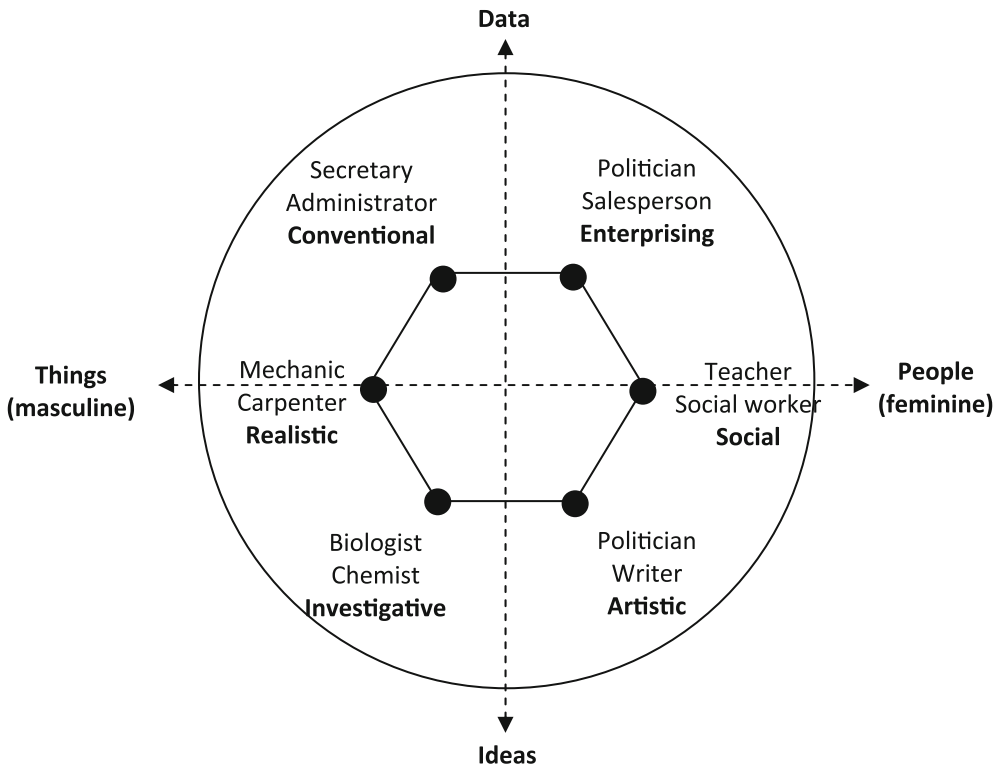

Fig. 1 The six personality types identified by Holland in their focus on people (feminine) vs. things (masculine) and in their focus on data vs. ideas. Source: (Lippa 2001) 
focused on things than is commonly believed. In the Netherlands, cultural norms have-to a greater degree than elsewhere-ensured that women do not explicitly demonstrate their ability to focus on things and/or do not develop it further (see e.g. Oldenziel et al. 2001). In addition, studies among first-year students in the Netherlands show that, in fact, only slightly more women than men have enterprising and social personality types (Need and de Jong 2002).

Women are not supposed to have technical knowledge

Cultural transfers ensure that people know how to behave 'normally'. Intentionally and unintentionally, people adopt the cultural norms and values of their environment, a process that is known as socialisation (Wilterdink and van Heerikhuizen 1993). In this regard, norms also exist about those who are (allowed to be) technically skilled and those who are not. A brief examination of recent Dutch history provides ample illustrations of the general opinion that women and technology do not go together.

Following the discovery of natural gas supplies in the Netherlands, politicians decided in the 1960s that the Dutch population should switch to natural gas. This required all electrical hobs in the country to be converted to gas hobs, at the expense of gas companies. These companies wanted to exclude women from the technical aspects involved in the conversion process as much as possible. For example, the municipal gas company in Hilversum warned housewives via a circular containing statements such as the following: 'The fitter will be in charge of disconnecting and connecting the gas equipment. HENCE, DO NOT DO THIS YOURSELF' and 'Do not bother the FITTER with UNNECESSARY questions' (Oldenziel et al. 2001).

Following World War II, hundreds of Vrouwen Advies Commissies ('Women's Advice Committees') were established, which currently still provide advice in matters relating to the structural design involved in house construction. At the time, the prevalent opinion within the construction industry was that the women in these committees should have their voices heard on the basis of their experience as housewives, rather than on the basis of any potential technical experience they may have had. The only way in which various women on these committees could continue to play a role within the construction industry, was by presenting themselves as housewives and by expressing their opinions on the basis of their expertise as housewives. Although the Women's Advice Committees were required to have technical expertise, and which they did, in order to be seen as serious discussants, they felt that a public display of their technical expertise would not go down well with their adversaries (Oldenziel et al. 2001).

Even now, Dutch girls still have a tendency to hide their technical expertise. This is particularly true during their adolescence, where girls may view their performance in technical and exact science subjects as incompatible with their feminine identity (Eck and van Volman 1999). As a result, girls will often present themselves as non-experts where computers are concerned, whereas boys generally tend to present themselves as experts, independent of any actual computer skills. International studies also point to patterns of acquired helplessness: girls' expectations of success are lower, they often deride their own capabilities and they give up earlier than boys when they encounter difficulties (Eck and van Volman 1999).

Another consequence of reiterating the dichotomy is that girls begin to believe that they have to explain and justify their ambitions and orientation towards things. The girls in our research who displayed a 'masculine' interest in things and technologies, justified this by linking their focus on things with their interest in people. Lieke, who wants 'to train immediately as a neurologist or heart surgeon' instead of becoming a doctor first-of which she has no intention-indicates her concern about appearing to be too technicallyorientated: 'I just hope that they will say: "Well, she is smart, but she is also good with people." 'Esther, who wants to work with buildings, says: 'I have always liked technical things, taking them apart and putting them together again', adding a bit later that: 'I care a lot about people.' When she points out that designing for people in Surinam is the most important purpose of her work, she adds: 'My aim is also to become a well-known architect.' Norwegian studies into girls who study information technology, also show that they need to do a lot in trying to justify why they, as women, wish to opt for a technical education (Corneliussen 2003). 
Gender segregation is much more distinctive in professions for which Dutch preparatory secondary vocational education provides the initial training ground, than for those professions which require a higher education. Only $2 \%$ of all girls in Dutch preparatory secondary vocational schools choose the technical sector. This is despite the fact that there is no reason to assume that girls at this level would have less technical talent than girls studying in Dutch senior general secondary education and pre-university education. One of the girls we interviewed, Marieke, a student in preparatory secondary vocational education, selected an education in care in spite of her strong technical orientation ('at home I would always take apart calculators'). Retrospectively, she regrets her choice and explains why at the time, against advice based on career testing, she did not choose a technical career: 'People talk a lot at school, so if you, for example, are about to choose a technical option, they may say that, uh... you are a butch, ${ }^{1}$ or something similar. They will say such things, since you are the only girl among all those boys. You are doing kind of boy things.' The word 'butch' clearly shows that this girl thinks she is seen in a masculine sense when undertaking technical education, as several other researchers also found (Rommes et al. 2005; Rommes 2010). Girls who did choose an education involving natural sciences are able to put this picture into perspective: 'It is true that mainly boys work there (technical professions) and that people see it as a male profession, which is not the case. But they won't think negatively about it (women in these professions).' Such fears of negative judgements about being a woman particularly come to the fore in qualitative interviews (see e.g. also Rommes et al. 2007). In questionnaires, most students in secondary vocational education indicate that they do not agree, with the statement 'Technology is not for girls' (AOB 2002).

For boys, the masculine identity of technology provides an added value in most cases and in some cases it is the most important reason for why they choose a technical career. Maarten, a student in preparatory secondary vocational education, had an internship at a construction site and loved being part of a male-dominated culture, where lots of jokes were made, and which made him feel more mature. Doing heavy and dirty labour shows that you are a man and this is the reason why it is valued so positively. Maarten: 'But, yes, of course, those stones are just like rocks. It is hard, but that is why you do the work. You should be able to take it. It will make you very strong.'

We believe there are two possible explanations for the distinctive gender segregation in Dutch preparatory secondary vocational education. First of all, previous research has shown that students who study at a lower level of education often come from more traditional families, where parents tend to have many stereotypical gender images and a stereotypical gender division of labour is in place (Spence and Helmreich 1978). A second explanation could be that it makes a significant difference whether or not students in preparatory secondary vocational education have to make a career choice much earlier on than their counterparts in Dutch senior general secondary education and pre-university education. After they have left primary education, students in the first and second year of preparatory secondary vocational education are already confronted with having to make a choice between the following sectors: Technology, Care and Well-Being, Society and Economics, and Agriculture. At this young age, adolescents—more so than in several years' time-form their own gender identity, rebelling against the other sex. One possible way of reducing gender segregation at these levels would be to allow such students to make a clear career choice when they are slightly older. This may also have a positive effect on boys, who are often-more likely than not-driven by the desire to be a man.

\footnotetext{
${ }^{1}$ She used the Dutch term 'manwijf'.
} 


\section{Career anchors}

In addition to the six personality types distinguished by Holland, a distinction according to 'career anchors' as proposed by Schein $(1985,1987)$ may be quite useful for elucidating the differences between men and women. A career anchor represents the core value that people are unwilling to give up when faced with a difficult challenge in their careers. For example, although everyone believes it to be important to be able to combine their private and professional lives in the work they do, some people prefer to give more priority to their private lives and may be more satisfied with having a job with less prestige. Based on empirical research, Schein identified eight career anchors. As we will suggest below, identity could perhaps be added as a ninth anchor (Table 1).

Secondary school students also develop career anchors which provide an insight into who they want to be. Not all their ideas may be equally realistic, since their career anchor has not yet sufficiently matured, but will become clearer through job experience. Nevertheless, career anchors influence their subsequent career choices (Compaan 1996) and determine which educational activities (choice of subject cluster, choice of sector, education/training) the students will pursue. Our research shows that the beginnings of career anchors can be found in adolescents aged 15-17 years. This is in contrast to a quantitative study conducted by Vinken et al. (2003), which did not find any clear anchors among adolescents. Vinken et al. (2003) based their conclusions on questionnaires which asked students to tick boxes and in which students indicated that they found almost all the options presented interesting. During our own research, we used in-depth, open interviews to ask students about the constitutive elements of their dream job and what they would dislike the most (van Damme 2004; Post 2005).

All students could be divided according to career anchors, even if some could be assigned to several anchors. The 'functional anchor' 2 was found to be the most popular among the students we examined, although 'security/stability' and 'service' also appeared to be popular. These findings are quite similar to those of Schein (1996), which is a second indication that a division according to career anchors is already possible at this age. However, trying to differentiate the 'challenge' anchor from that of 'entrepreneurship' and the 'functional' anchor posed more of a difficulty. Would the next challenge be in the same area or would the person in question opt for greater variation? More extensive research is required before any definitive conclusions can be drawn about the distribution across various career anchors (Table 2).

The concept of career anchors, even more so than the concept of personality type used by Holland, shifts the attention from the differences between women and men to those between women. It becomes clear that both boys and girls do not form homogeneous groups. Girls and boys who share the same career anchor probably have more in common with each other than with their peers of the same sex who have a different anchor. This means that boys and girls are often attracted to certain careers for the same reasons. International research - mainly focused on students with a higher education in the USamong hundreds of graduates and professionals shows that the eight career anchors can be found among both men and women, but not to the same extent (Schein 1987; Igbari and Baroudi 1993). Women tend to be more focused on lifestyle than men, although this anchor is on the increase among men. This might apply even more so in the Netherlands, a country

\footnotetext{
${ }^{2}$ We will use the term 'functional anchor' instead of 'technical-functional', so as to avoid the unintended association with technical professions.
} 
Table 1 Edgar Schein's career anchors

1. Technical/functional competence (We use the term functional anchor instead of technical-functional anchor in order to prevent the unintended association with technical professions).

These people discover during their career that they are very talented and highly motivated for a certain type of job. Pursuing their talents and the satisfaction they derive from the knowledge of being professionals gives them 'a real kick'. Their competence may focus on any work environment and, consequently, does not have to be technical.

2. Managerial competence

These people prefer to become general managers rather than specialising in a certain functional field. They aspire to obtain a high status in the hierarchy within the organisation and are driven by the possibilities of additional responsibilities and contributions to the success of the organisation and for a high salary.

3. Autonomy/independence

People who have 'autonomy' as their career anchor cannot stand to be restricted by the rules of other people, procedures, working hours, clothing regulations and other standards of an organisation. They want to do things their own way, at their own pace and according their own standards.

4. Security/stability

These people are more engaged in the contents of the job than in the nature of the job itself. They want to feel safe and secure and often look for a job within an organisation that offers a permanent contract, has a reputation of avoiding dismissals, offers proper pension provisions and secondary elements of remuneration, and is known to be strong and reliable.

5. Service/dedication

Some people choose a certain profession in order to achieve certain ideals. They are more focussed upon ideals such as serving humanity, helping a country or improving the environment than on actual talents or fields of competence.

6. Pure challenge

These people find pleasure in their jobs through accepting and meeting challenges. They are competitive and ambitious to a very high degree and do not concentrate on a single functional skill, but constantly seek variation and new challenges. Just like 'fighters' they look for confrontation with the 'enemy' and seek to prove their own superiority.

7. Lifestyle

Lifestyle people feel that it is important to combine their individual needs with their family and career. They would rather look for an organisation with a flexible attitude that for a specific programme.

8. Entrepreneurship

Entrepreneurs want to create a new company of which they are the owner by developing new products or services or to build up an organisation according to their own specifications. They have a creative urge which is linked to their own efforts and can survive on their own. They desire to be economically successful.

9. Identity

Although Schein has not included the value of identity as a separate value, this career anchor in particular appears to be of concern to students. In our study, students who seemed to be mainly motivated by the status of a profession, such as a pop star, stewardess or astronaut, fall within this value. We also include students who seem to be motivated by the 'masculine' or 'feminine' image of a profession.

Source: (Schein 1975, 1985, 1987)

known for the large number of women working in part-time jobs. Men generally tend to be focused on 'functional' careers and 'management' (Igbari and Baroudi 1993). We found similar results in our own research among students. One remarkable finding is how important the 'security' anchor is among men in this relatively young generation. Apparently, the ideal of being the main breadwinner is still important to these boys. Girls 
Table 2 Distribution of career anchors in the study

\begin{tabular}{lllll}
\hline & $\begin{array}{l}\text { Girls preparatory } \\
\text { secondary } \\
\text { vocational } \\
\text { education }\end{array}$ & $\begin{array}{l}\text { Girls senior general } \\
\text { secondary education/ } \\
\text { pre-university } \\
\text { education }\end{array}$ & $\begin{array}{l}\text { Boys preparatory } \\
\text { secondary } \\
\text { vocational } \\
\text { education }\end{array}$ & $\begin{array}{l}\text { Boys senior general } \\
\text { secondary education/ } \\
\text { pre-university } \\
\text { education }\end{array}$ \\
\hline $\begin{array}{l}\text { Functional } \\
\text { Managerial }\end{array}$ & 1 & 1 & 4 & 1 \\
$\begin{array}{l}\text { Autonomy } \\
\text { Security }\end{array}$ & 1 & 1 & & 1 \\
Service & 1 & 4 & 2 & 3 \\
$\begin{array}{l}\text { Pure challenge } \\
\text { Lifestyle }\end{array}$ & 1 & 1 & 1 & \\
Entrepreneurship & 1 & 1 & & \\
Identity & 1 & & & 5 \\
Total & 4 & 9 & 8 & \\
\hline
\end{tabular}

often appeared to have a 'service' anchor, even if this was regularly combined with other anchors, e.g. the 'functional' anchor. ${ }^{3}$

\section{Modifications to Schein}

Before applying the concept of career anchors to indicate how education and careers can be made attractive to girls and boys, we will refine the theory of career anchors in order to gain a better understanding of women and the choices they make. Schein's theory is not without criticisms. One can clearly see that Schein initially developed his career anchors by carrying out research into men only (Schein 1987). As a consequence, he encountered problems when trying to apply his career anchors to women. Approximately $20 \%$ of female university graduates could not be classified (Schein 1987). On the basis of our research into Dutch secondary school students, we recommend three modifications:

- Adding 'identity' as an anchor;

- Removing the gender-specific connotation that Schein gave to the 'challenge' anchor;

- Anchor combinations: upholding two or more core values.

Although DeLong (1982) proposed that identity should be included as a separate anchor, Schein never viewed the value 'identity' as a separate anchor. Schein subsumed identity under the 'security' anchor, where it formed part of a strong loyalty to the employer. Among the adolescents in our research, however, we found that the 'identity' anchor (what image does the profession have and who do you want to be by choosing this profession) was very important and not necessarily connected to wanting to work for just one organisation. For example, one girl was keen to develop her singing abilities by becoming a pop star. Since she viewed this as a less attainable dream, she intended to become a journalist and 'write all day long', so as to become very good at that. In addition to functional motivation, the image of the profession clearly affected her preferences. The

\footnotetext{
3 In Table 2, the three girls who combined the 'service' anchor and the 'functional' anchor have been grouped under the 'service' anchor.
} 
'identity' career anchor, and in particular how others see you, will definitely be more important to young people during their adolescence than the adult employees examined by Schein, since this is a phase in which they develop their own, independent identity. The gender identity of a profession can also be a core professional value, as the following examples will show.

For Josefien, the feminine image of a profession appears to be the most important factor, with the status of the profession as an additional important factor. She would like to become a stewardess, 'with such a lovely outfit', but later on changed her ideal profession to midwife, when she realises that this profession presents a more 'dedicated' image. When we asked her which profession she would never be interested in, she immediately replies 'cleaner' without any hesitation. Clearly, she is not aware that cleaning is one of the most important duties carried out by both a stewardess and a midwife. This suggests that her choice of career is predominantly based on the profession's (feminine) image.

The image of a profession could also be a reason for not choosing a particular profession, especially when it does not fit with one's self-image. This was the case with Marieke, whom we mentioned earlier, and who was afraid of being told she was 'a butch'. The belief that women increase their attractiveness to men through their technical helplessness and, conversely, that men increase their attractiveness through a nonchalant display of 'inborn' technical talent, is prevalent in our culture (Rommes et al. 2005; Rommes 2010).

A second modification to Schein's theory concerns his interpretation of the 'challenge' anchor, which he developed on the basis of research in the US, in particular, among military pilots. Schein's description of people with this career anchor as warriors that 'define their careers essentially as daily combat or competition in which winning is everything' fits less well with non-militaristic, European culture, where competition is valued less, especially by women. For example, recent work by Sools (2002) demonstrates how ambition is a very precarious issue in the Dutch culture, and particularly so for women, even if it is a necessary precondition for progressing in one's career. As a career anchor, 'challenge' could easily be described in more gender- and culture-neutral terms. One way of doing so would be to underline that challengers are not so much interested in beating others, but rather in trying to find ongoing personal challenges and wanting to achieve excellent performances, regardless of the professional area involved.

Reinterpreted in this way, challengers could be more easily classified, particularly in relation to girls with an interest in natural sciences. We already mentioned Lieke, who believed that being a doctor was not a sufficient challenge and who wanted 'to train immediately as a neurologist or heart surgeon'. Three other girls who displayed an orientation towards the natural sciences also showed aspects of challenge: they made no secret of their ambitions and wanted to do well in their professions, no matter what. For girls orientated towards the natural sciences, we particularly expected to find the 'challenge' career anchor, since technical careers are generally known as 'difficult' and 'not suitable for girls'.

This brings us to the third and final modification to Schein's theory: even if one anchor often takes centre stage, people will often view a second or third related anchor as equally important. For example, girls who choose anchors and professional areas that are aspecific insofar as gender is concerned, will show the need to 'soften' their choice by indicating or selecting anchors with more feminine connotations, such as 'service'. ${ }^{4}$ The four girls we

\footnotetext{
${ }^{4}$ We will leave aside the issue of whether such girls are actually interested in these feminine choices and values, or whether they merely say so, because they are concerned about their image.
} 
mentioned with an interest in natural sciences, chose a profession involving natural sciences that was clearly focused on improving the world. Values related to service provision were just as important to them as the ambition to do well in their professions (van Damme 2004). ${ }^{5}$ One possible explanation might be that the 'service' anchor is more important to women than the people- or thing-orientated character of different forms of education, as described by Holland. Technical education aimed at service provision, such as medical education, tropical forestry, technical environmental studies, and the course of study entitled 'Energy and environmental research' in Norway (Lagesen 2004), are extremely popular with girls, even if these are otherwise just as technical as other natural science studies.

Our hypothesis is that girls who display 'masculine' ambitions, will only find these acceptable if such ambitions can be combined with the more 'feminine' value of service. These students have two values that they do not want to give up: their ambitions to create something as an entrepreneur, expert or through a pure challenge, and their ambition for service provision. This type of anchor combination can be observed in both men and women. It is likely that men with stereotypical feminine interests or anchors compensate for this by simultaneously following a 'masculine' anchor, such as wanting to be a manager in a hospital or a school.

The concept of a career anchor allows us to explain why women with interests and core values which, in principle, fit well with technical professions, still divert to other professional areas. Where Holland establishes a one-on-one connection between personality type and professional fields (on the assumption that certain personal qualities are most adequately expressed in certain professions), the application of Schein's theory shows that in many cases a single core value can be realised in different professional fields. This means that students are less attracted to one single professional area than Holland assumes. Only persons with a 'functional' anchor focus on a specific area. As a consequence, a basic interest in technology as such would only lead 'functional' types to choose a technical profession. For all other types, an interest in technology is transformed into learning and working in a technical area, as long as they can realise their core values in that field. These students feel less bound to one particular professional area, since they are in principle able to realise their anchor in different areas. For example, a boy who opted for 'security' was thinking of a job in the hotel and catering industry, in security services or in technology.

This means that many women who, in principle, recognise their career values in technical professions, make a different choice as long as the masculine image of technology persists. Female students in Dutch pre-university education, who take a Nature and Technology study cluster, predominantly tend to choose medical and paramedical forms of education (Inspectie van het Onderwijs 2002/2003). Young people will also try and realise their secondary or tertiary anchors, which particularly for girls, will tend to be the 'service' anchor or the 'identity' anchor.

The anchors also show that many young people do not want to limit themselves to one particular professional field. Changing professions is not an obvious choice for 'functional' and 'security' personality types; the core value lies with the 'challenge' anchor, but is not

\footnotetext{
5 Schein's values which relate to service provision are of a different character than the people-focused personality type in Holland's model. This was clearly suggested by the attitude of the two girls who wanted to become doctors. In our research, the ideals related to service provision found particular expression in wanting to improve health care through more accurate diagnoses and treatment. Both girls found having to confront the suffering of patients to be the least attractive part of the job and did not believe that they had anything special to offer in this regard. However, the social personality type in Holland's model is specifically attracted to these aspects of the medical profession.
} 
excluded from other anchors. Changing professional sectors is a means of realising the core professional value in a more adequate manner. In that way, one's career will evolve through various professions. ${ }^{6}$

\section{Inaccurate ideas about technical professions}

Translated into career anchors, the ideas that students have about technical professions seem to fit with the 'functional', 'security/stability' and 'challenge' anchors.

The 'functional' anchor refers to a profession in which one can immerse oneself in a single topic, on which one is the expert. This is the most prevalent image of technical professions among the students we examined. Ashmir (pre-university education) has a strong affinity with this picture and describes a scientist in the following way: 'He develops new types of blades and equipment for a certain kind of foam, and has studied the highest forms of chemistry, mathematics and biology, so he knows everything about them...' Marijke believes this anchor does not suit her: 'For example, if I look at what is involved in studying natural sciences, then I think it delves quite deeply into certain things, which makes me think: "Why would you need that?" What was it that we were doing last time? Oh, yes, light waves. Well, to find out exactly what the frequency is, does not appeal to me much, since it focuses too much on one specific thing. I prefer to look at certain things in a more general way, to see how things are related, rather than taking an in-depth look at really small things.'

Some of the boys share the expectation that a technical profession will provide security, particularly those professions which require completion of secondary education. They emphasised things such as regular hours, permanent colleagues, predictable pay and working within an organisation with clear assignments.

The 'challenge' anchor is also frequently linked to technical professions. Many students describe these professions as difficult and physically taxing. Although this deters some students, others find the challenges they pose very attractive.

Werner, a student in preparatory secondary vocational education, mentions the following: 'You are always facing new problems, such as: it could be broken this time, but it could also be something else; and another time you will need to replace it. You are occupied with something all the time.' And in the words of Esther, a student in senior general secondary education: 'At a career fair, I would tell other students that being an architect would enable you to help other people, as well as being able to use your imagination. That you can make up your own assignments, which you then try to carry out. A desire to create. You will need to be able to think clearly, as well as being good at mathematics and physics. Being able to look at things from many sides.'

Finally, the 'identity' career anchor is strongly connected to technical professions. Virtually all students associated technology with men or masculinity. Furthermore, technical professions do not seem to have a high status among students. For example, students do not want to become a scientist or a 'boring, absent-minded professor', who focuses on a small, irrelevant field of knowledge. Research among the Dutch population has shown that

\footnotetext{
${ }^{6}$ Brousseau and Driver (1998) describe this process as spiral-like or transitory. The reason for a new job is to widen one's knowledge and skills, as well as to gain different experience. According to Brousseau, personal development, creativity and novelty are important to this group. Changing professional sectors is used to realise one's core professional value in a more satisfying way.
} 
the status of scientists is regarded almost twice as high among older people than among the younger generation (Schildmeijer et al. 2004).

In principle, it should be possible for technical professions to match, or be matched to, all career anchors. In our research, we found various other career anchors, such as 'autonomy', 'security', 'functional', 'service' and 'identity', among young people who considered choosing a technical profession. For example, Erik wanted to become a structural manager, since it would allow him to do project-based work and give him plenty of freedom to do other things in his life. Ashmir looked for security in his future profession and therefore saw technology as an option, whereas Rodney opted to be a pilot based on motives relating to service provision. We previously mentioned Maarten: a technical profession provides a (masculine) identity which appeals to some people. Research among IT staff indicated the presence of all career anchors amongst IT technicians (Ramakrishna and Potosky 2001).

\section{A new approach: beyond the two sexes}

Measures aimed at increasing the number of women in technical education and professions should take notice of the differences between women themselves. It is certainly useful to reinforce the image of technical professions as people-orientated and as providing a service. The image that women are only attracted to the people-orientated side of things, or that technology should not be too technical or too difficult for women, should certainly not be reinforced. This also applies to other measures that have been proposed, such as childcare and part-time work (Booy and Joukes 2004; FNV 2002). Such proposals are more suitable for men who have 'lifestyle' as their main anchor than for ambitious women. A one-sided plea for lifestyle measures and a simplification of technical studies would even deter women who thrive on challenges, which includes many of those interested in natural sciences.

A novel approach is required. The one we would suggest contains the following three components:

- To challenge the masculine image of technology (and the natural sciences) and the focus on things;

- To facilitate jobs which match various career anchors and personality types;

- To widen the image of technical professions: communicating their appropriateness for various anchors and personality types.

These last two measures will not only attract more women, but will also have a major positive side-effect, in that technology will become more attractive to men who currently do not opt for technology. Only men who are predominantly motivated by the masculine image of technology will then probably no longer choose a technical profession.

If involvement with technology is no longer viewed as masculine, then the number of women in technical education and professions is likely to increase, i.e. when women will be able to be feminine while at the same time being able to focus predominantly on things and challenges. The masculine image of technical professions could be challenged in several ways (Fig. 2):

- By providing more role models (MacKeogh 2003);

- Through intentionally mixing masculine and feminine elements, such as girls in England who were challenged to create a website for their favourite boy band (Pitt 2004); 


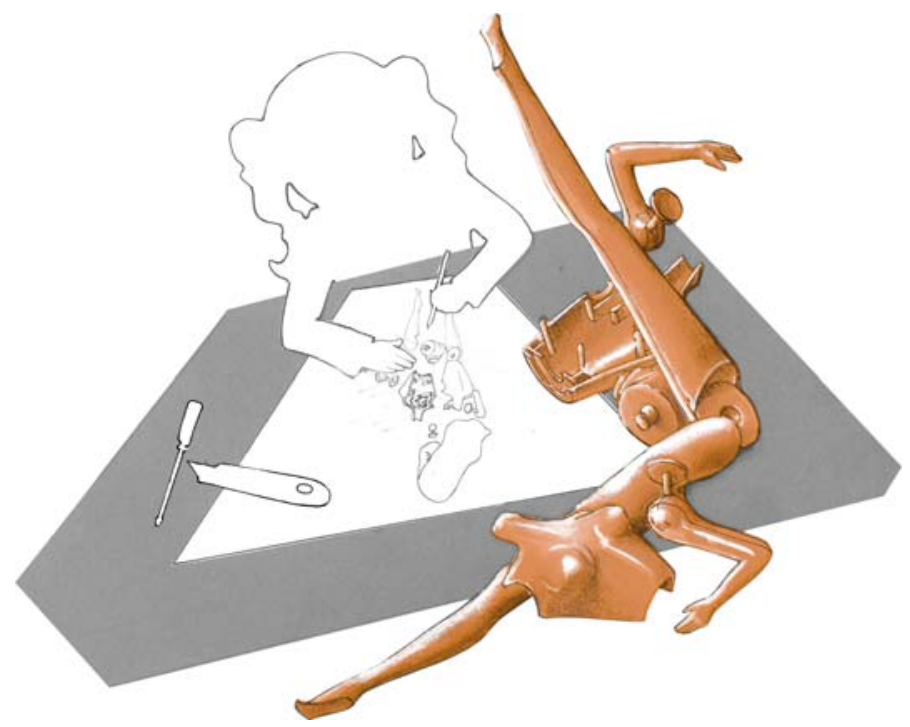

Fig. 2 Intentionally mixing masculine and feminine elements. Source: Stichting Toekomstbeeld der Techniek, design by Ella Nitters

- By recruiting only women for certain technical courses and education, such as Technika 10, girls-only vocational schools, etc.;

In this way, women will explicitly be given the message that technology-in all its various aspects-is meant for them.

Challenging the masculine image is a necessary, although insufficient, condition for the recruitment of women. The theories proposed by Holland and Schein emphasise that women differ greatly between themselves and aim for different values in their professional lives. An increasing number of women, as well as men, may be reached when educational institutions and technical employers create career opportunities that address the whole range of career anchors.

Anchors such as 'entrepreneurship', 'service' and 'identity-in-another-format', could be used to recruit new target groups. In addition to the actual realisation of potential, the images conveyed will need to make clear that technical professions match different career anchors.

There are various reasons for currently putting more effort into obtaining a more balanced male-female distribution within technical professions, as well as encouraging new images of such professions. First of all, many employers expect that there will be a shortage of technicians in the near future and are at present more than willing to make their organisations more accessible to target groups that are currently underrepresented. Secondly, the content of technical professions is changing, which makes them more attractive to different personality types and anchors. As a result of the knowledge economy, globalisation and the strong emphasis on work specifically tailored to consumer groups, interdisciplinary cooperation is becoming increasingly more important, as is a decline in the 'pure' technical character of jobs (Bras-Klapwijk 2005; Florida and Tinagli 2004). Moreover, with a view to improving their customer relationships, technical experts are required to develop their communication, entrepreneurial and problemsolving skills. 
As a result, entrepreneurial, social and artistic qualities are increasingly seen as valuable commodities in technical fields. Making technology accessible to people with different personality types and career anchors fits well with the economic developments mentioned previously. In fact, most young people have a very limited, and often quite dated, view of technical professions.

Thirdly, the operational environment of employers has also become more dynamic and complex. A company that is characterised as having a diverse work force, is well able to cope with differences and has more insight into social trends. Attracting women and other groups which could bring in new talents, increases their chances of economic success. Finally, men also will find themselves more at ease in technical professions if there is room for them to realise diverse core values.

To conclude, we think that a modified version of Schein's theory could offer a way forward in the development of new educational and career trajectories, thereby making a significant contribution to a larger and more diverse group of young people with an interest in technology.

Open Access This article is distributed under the terms of the Creative Commons Attribution Noncommercial License which permits any noncommercial use, distribution, and reproduction in any medium, provided the original author(s) and source are credited.

\section{References}

AOB Zuid-Nederland. (2002). Het imago van techniek en technische beroepen en opleidingen bij leerlingen van 2-vmbo in Noord-Brabant. ATB. maart.

Bongers, F., \& de Groot, H., et al. (2003). Digitaal kapitaal; Internationale beleidsvergelijking van ICT in het onderwijs en op de arbeidsmarkt. Utrecht: Dialogic.

Booy, C., \& Joukes, G. (2004). Ruim baan voor vrouwelijk talent; Meer meisjes en vrouwen naar bèta \& techniek. Amsterdam: Axis/ICT-punt, Delft, VHTO.

Bras-Klapwijk, R. M. (Ed.). (2005). Techniek als menselijk ontwerp; Nieuwe opleidings—en loopbaanroutes voor jongeren, Stichting Toekomstbeeld der Techniek, Den Haag.

Brousseau, K. R., \& Driver, M. J. (1998). Career view concepts. Roadmaps for career success. An overview. Lund: Decision Dynamics Group.

Buis, T., Hendrix, K., \& Frietman, J. (2003). Technomonitor 2003. Een kwantitatieve analyse van het technisch onderwijs en de technische arbeidsmarkt. Nijmegen: Kenniscentrum Beroepsonderwijs Arbeidsmarkt.

CBS. (2004). www.cbs.nl/nl/cijfers/statline

Cockburn, C., \& Ormrod, S. (1993). Gender \& technology in the making. London: Sage.

Compaan, E. (1996). Ontwikkeling en meten beroepsinteresses. In A. Breed \& A. Kooreman (Eds.), Trends; Psychologie in arbeid en loopbaan (pp. 111-134). Lisse: Swets \& Zeitlinger.

Corneliussen, H. (2003). Male positioning strategies in relation to computing. In M. Lie (Ed.), He, she and IT revisited; New perspectives on gender in the information society (pp. 103-134). Oslo: Gyldendal Akademisk.

DeLong, J. (1982). The career orientation of MBA alumni: A multidimensional model. In R. Katz (Ed.), Career issues in human resource management. New York: Prentice Hall.

Eccles, J. S. (1987). Gender roles and women's achievement-related decisions. Psychology of Women Quarterly, 11, 135-172.

Eck, E., \& van Volman, M. (1999). Leuke hobby, saaie baan? Eindrapport Evaluatie Technica 10 Plus Amsterdam. SCO Kohnstamm Instituut/Vrije Universiteit.

Florida, R., \& Tinagli, I. (2004). Europe in the creative age. Demos, February.

FNV. (2002). Vrouwen in de bouw. Ineke van Westrienen: Jonge mannen moeten voor doorbraak zorgen. Bouwmagazine. juli.

Holland, J. (1997). Making vocational choices: A theory of vocational personalities and work environments (3rd ed.). Odessa, FL: Psychological Assessment Resources.

Igbari, M., \& Baroudi, J. (1993). A short-form measure of career orientations: A psychometric evaluation. Journal of Management Information Systems, 10, 131-154. 
Inspectie van het Onderwijs. (2004). Onderwijsverslag 2002/2003, Inspectie van het Onderwijs, Utrecht.

Lagesen, V. A. (2004). Computer science-Careers or computing? Inclusion through 'secularization' of ICT. In N. Oudshoorn, E. Rommes, \& I. van Slooten (Eds.), Strategies of inclusion: Gender in the information society; Surveys of women's user experience (pp. 363-414). Trondheim: NTNU.

Lippa, R. A. (2001). On deconstructing and reconstructing masculinity-femininity. Journal of Research in Personality, 35, 168-207.

MacKeogh, C. (2003). Women in technology and science role model project. In M. Lie \& K. Sorensen (Eds.), Strategies of inclusion: Gender in the information society. Vol. I: Experiences from public sector initiatives (pp. 401-418). Trondheim: NTNU.

Need, A., \& de Jong, U. (2002). Persoonlijkheidskenmerken en seksespecifieke inkomensverwachtingen in het hoger onderwijs. Sociale Wetenschappen, 45(3), 53-69.

OC\&W (Ministerie van Onderwijs, Cultuur en Wetenschap), EZ \& SZW. (2003). Deltaplan Bèta/techniek. Actieplan voor de aanpak van tehorten aan bèta's en technici. Den Haag: OCW.

Oldenziel, R., Berendsen, M., Albert de la Bruhèze, A. A., Cieraad, I., van Dorst, C. J. M., Drogendijk, J. C., et al. (2001). Het huishouden tussen droom en werkelijkheid; oorlogseconomie in vredestijd, 19451963: In J. W. Schot, H. W. Lintsen, A. Rip, \& A. A. Albert de la Bruhèze (Eds.). Techniek in Nederland in de Twintigste Eeuw, deel vijf, Huishouden/Medische Techniek. Stichting Historie der Techniek, Walburg Pers.

Orenstein, P. (2000). Schoolgirls; Young women, self-esteem, and the confidence gap. New York: Anchor Books.

Pitt, L. (2004). IT beat: Bringing pop and glam to IT. In C. MacKeogh \& P. Preston (Eds.), Strategies of inclusion: Gender in the information society. Vol. II: Experiences from private and voluntary sector initiatives (pp. 219-240). Trondheim: NTNU.

Post, C. (2005). Imago-onderzoek techniek, beelden van jongeren over techniek en technische beroepen. Den Haag: Afstudeerverslag, STT/Beweton/Universiteit Utrecht.

Ramakrishna, H., \& Potosky, D. (2001). Structural shifts in career anchors of information systems personnel: A preliminary empirical analysis. Journal of Computer Information Systems, 42(2), 83-89.

Rommes, E. W. M. (2010). Heteronormativity revisited; Teenagers educational choices, sexuality and soaps. In S. Booth, S. Goodman, \& G. Kirkup (Eds.), Gender, IT and sites of learning. IG Publisher.

Rommes, E., Faulkner, W., \& van Slooten, I. (2005). Changing lives: The case for women-only vocational technology training revisited. Journal of Vocational Education and Training, 57(3), 293-318.

Rommes, E., Overbeek, G., Scholte, R., Engels, R., \& de Kemp, R. (2007). “'I'm not interested in computers', Gender-based occupational choices of teenagers”. Information. Communication \& Society, 10(3), 299-319.

Schein, E. H. (1975). How career anchors hold executives to their career paths. Personnel, 52, 11-24.

Schein, E. H. (1985). Career anchors: Discovering your real values. San Diego, CA: University Associates.

Schein, E. H. (1987). Individuals and careers. In J. W. Lorsch (Ed.), Handbook of organizational behavior (pp. 155-171). New York: Prentice-Hall.

Schein, E. H. (1996). Career anchors revisited: Implications for career development in the 21st century. MIT Sloan School of Managament, Society for Organizational Learning, Working Paper.

Schildmeijer, R. J., Frerichs, R., \& Kanne, P. J. (2004). Kennis van de kenniseconomie. De beleving van wetenschap en techniek door de Nederlandse bevolking. Amsterdam: Stichting Weten.

Sools, A. (2002). De paradox van de ambitie. Een cultuurpsychologisch onderzoek naar de hardnekkigheid van genderonderscheid in een organisatiepraktijk. Nijmegen University Press.

Spence, J. T., \& Helmreich, R. L. (1978). Masculinity \& femininity; Their psychological dimensions, correlates, \& antecedents. Austin \& London: University of Texas Press.

van Damme, I. (2004). Arbeidsidealen van jongeren. Stagerapport: STT/Beweton/Radboud Universiteit Nijmegen.

van Diemen, D., Kuiper, E. R., \& Mulder, B. (2004). Women creating technology neighbourship. Brussels: I.O. Metal, Municipal Technology Centres.

Vinken, H., Ester, P., van Dun, L., \& van Poppel, H. (2003). Arbeidswaarden, toekomstbeelden en loopbaanoriëntaties. Een pilotstudy onder jonge Nederlanders. Tilburg: OSA.

Wajcman, J. (1993). Feminism confronts technology. Cambridge: Polity Press.

Wilterdink, N., \& van Heerikhuizen, B. (1993). Samenlevingen. Wolters-Noordhoff, Groningen. $3^{\mathrm{e}}$ druk. 